\title{
PEMAKAIAN BAHASA INDONESIA \\ DALAM KARYA TULIS MAHASISWA \\ (Suatu Kajian dengan Pendekatan Analisis Wacana) \\ Ardianto
}

STAIN Manado

\begin{abstract}
Abstrak
Penelitian ini mengkaji pemakaian pemarkah keterpaduan wacana secara deskriptif dengan menganalisis berdasarkan pendekatan analisis wacana. Sumber data ialah buku skripsi mahasiswa STAIN Manado.

Hasil penelitian menunjukkan bahwa pemarkah keterpaduan wacana yang digunakan oleh para mahasiwa ialah pengulangan leksikal, transisi, substitusi, pemberian con toh, pernyataan kembali, syarat, kata penghubung, referensi, praanggapan, pelesapan, sebab akibat, alasan, penambahan, proverba, deiksis, antonimi, alternatif, kata tumpuan, simpulan/hasil, kontras, dan pengurutan. Di antara deretan pemarkah keterpaduan itu, dua di antaranya yang dominan yaitu pengulangan leksikal dan transisi.

Dari segi keterpaduan penggunaan pengulangan leksikal mahasiswa mempunyai kebiasaan yang sama untuk menggunakan pemarkah pengulangan leksikal. Demikian pula bentuk penanda transisi, hampir setiap mahasiswa menggunakan hal yang sama. Proporsi kesalahan mahasiswa pada kedua bentuk pemadu wacana itu pun relatif sama. Artinya, mahasiswa belum memahami cara pemakaiannya. Berdasarkan hal ini, dapat disimpulkan bahwa mahasiswa belum terampil menyusun wacana yang kohesif sebagai dasar dalam penyusunan skripsi sebagai karya tulis ilmiah.
\end{abstract}

Kata Kunci: Bahasa Indonesia, wacana, karya tulis ilmiah. 


\section{A. Pendahuluan}

Bukti-bukti hasil penelitian empiris menunjukkan bahwa kualitas berbahasa Indonesia golongan terdidiktermasuk di sini mahasiswa dan sarjana masih cukup rendah. Sadtono ${ }^{1}$ dalam penelitiannya tentang penggunaan bahasa tulis mahasiswa calon sarjana, menunjukkan bahwa para mahasiswa itu masih banyak membuat kesalahan mulai dari kesalahan tata kalimat, penyusunan paragraf, ejaan, sampai dengan pembentukan kata. Demikian pula, penelitian Syafi'ie ${ }^{2}$ tentang pemakaian bahasa Indonesia dalam karya tulis mahasiswa calon tenaga kependidikan (LPTK) juga menemukan fakta bahwa pemakaian bahasa Indonesia kalangan mahasiswa calon pendidik itu sangat rendah.

Rendahnya kualitas kemampuan berbahasa Indonesia golongan terdidik juga menjadi kesimpulan penelitian Tallei $^{3}$ dalam penelitiannya terhadap sejumlah dosen peneliti di IKIP

\footnotetext{
${ }^{1}$ E. Sadtono, "Bahasa Indonesia Tertulis Golongan Terdidik (Sarjana) di Indonesia.", dalam majalah Pengajaran Bahasa dan Sastra. Thn. I No. 5. Tahun 1976. Jakarta: Pusat Pembinaan dan Pengajaran Bahasa.

${ }^{2}$ Imam Syafi'i, "Analisis Kesalahan Berbahasa Indonesia dalam Menulis Mahasiswa Tiga IKIP di Jawa", Disertasi (Malang: IKIP Malang, 1984).

${ }^{3}$ Tallei, "Pemakaian Bahasa Indonesia dalam Buku Laporan Penelitian Dosen LPTK di Sulawesi Utara", Laporan Penelitian (Manado: IKIP Manado, 1992.).
} 
Manado dan FKIP Universitas Sam Ratulangi di Gorontalo. Dalam penelitian itu terungkap bahwa responden kurang mampu memadukan kalimat-kalimat untuk membentuk paragraf yang tersusun secara logis. Hal yang sama juga dicatat oleh Sugihastuti $^{4}$ dalam pengamatannya terhadap bahasa laporan penelitian. Dikemukakannya bahwa banyak kesalahan berbahasa yang dilakukan oleh para peneliti dalam menyusun laporan penelitiannya. Lebih lanjut dikemukakan Sugihastuti, kesalahan-kesalahan bahasa para peneliti itu bermula dari ketidaktepatan menerapkan Pedoman Umum Ejaan Bahasa Indonesia yang Disempurnakan, pemenggalan kata, diksi, penulisan kata, pemakaian bentuk di mana dan yang mana, pemakaian kata yang mubazir, penghilangan afiks, pemakaian kata depan yang kurang tepat, dan sebagainya.

Salah sate syarat dalam penulisan karya tulis pada umumnya, dan terlebih pada laporan hasil penelitian ilmiah ialah kecermatan pemakaian bahasa. Pemakaian bahasa yang tidak cermat dapat menyebabkan terganggunya penyampaian pesan. Bukan hanya pesannya tidak sampai, melainkan juga dapat menimbulkan tafsiran ganda atau ambiguitas. Bahasa dalam karya tulis ilmiah harus baik, lugas, padat, dan jelas. Bahasa yang baik dalam karya ilmiah ialah bahasa yang baku, baik dari segi kaidahnya, maupun dari segi istilah yang digunakan Lugas berarti eksak, tidak berbelit-belit. Dengan kata lain, uraiannya langsung ke persoalan dan tidak menimbulkan tafsiran yang kabur atau ganda. Padat berarti efisien dalam pemakaian kata dan struktur. Terlalu banyak menggunakan kalimat kompleks untuk menjelaskan persoalan, malah dapat mengaburkan persoalan itu sendiri meskipun diakui bahwa dalam pengungkapan masalah-masalah yang abstrak, pemakaian kalimat kompleks tidak dapat dihindari. Namun demikian, efisiensi pemakaian bahasa ini tidak harus mengorbankan kelengkapan cakupan makna.

Di dalam karya tulis ilmiah, kata-kata yang ditulis haruslah sesuai dengan konteks kalimat yang disusun. Kesesuaian kata dengan konteks, baik konteks kalimat maupun karangan secara keseluruhan akan melahirkan urutan koherensi (keterpaduan) wacana. Bagaimanakah pemakaian bahasa Indonesia khususnya para mahasiswa. Pertanyaan tersebut perlu dikaji mengingat mahasiswa sebagai kelompok terdidik harus mampu menggunakan

\footnotetext{
2003), hlm 8

${ }^{4}$ Sugihastuti, Bahasa Indonesia dari Awam, Mahasiswa, sampai Wartawan (Yogyakarta: Gama Media,
} 
bahasa Indonesia dengan baik dan benar terlebih dalam bahasa tulis. Mahasiswa yang juga sebagai calon ilmuwan haruslah memiliki keterampilan menyusun kalimat untuk menyampaikan pikiran dan perasaannya. Ketepatan isi pikiran itu tercermin dari susunan kalimat yang ditulisnya. Jika mahasiswa ingin menulis, ingin berbahasa dengan meyakinkan dan dengan cara yang menyenangkan, mereka harus mahir menyusun kalimat efektif. Kalimat efektif itu dapat terbentuk melalui berbagai penguasaan teknis kebahasaan seperti penulisan kata, penerapan pedoman Ejaan yang Disempurnakan (EyD), ketepatan struktur kata, diksi, termasuk di sini penguasaan atas sejumlah alat kebahasaan (kohesi wacana) sebagai pemarkah keterpaduan wacana.

Penelitian ini difokuskan pada aspek wacana, dalam arti bagaimana kalimat ditata sehingga mencapai sebuah wacana yang padu atau runtut. Dalam menata kalimat menjadi sebuah wacana, dibutuhkan alat-alat kebahasaan khusus yang disebut penanda wacana. Karena itu, masalah penelitian ini dirumuskan (1) apakah para mahasiswa menggunakan penanda wacana secara tepat dalam karya tulis? Dan, (2) jika penanda wacana itu digunakan secara tepat, penanda wacana mana yang digunakan?

\section{Tujuan Penelitian}

Penelitian ini bertujuan (1) menjelaskan ketepatan penggunaan penanda wacana oleh para mahasiswa dalam karya tulis yang terdiri dari mahasiswa jurusan Tarbiyah dan Syari'ah STAIN Manado, dan (2) mendaftarkan dan mengklasifikasikan penanda wacana yang digunakan oleh para mahasiswa dalam karya tulis yang terdiri dari mahasiswa jurusan Tarbiyah dan Syariah STAIN Manado.

\section{Kajian Teori}

A. Analisis Wacana Sebagai Pendekatan Penelitian Kebahasaan

Penggunaan metode analisis wacana dalam pengajaran bahasa semakin terasa pentingnya mengingat bahwa tataran bahasa yang tertinggi bukanlah kalimat melainkan wacana. Karena itu, kesadaran akan kelemahan pengajaran bahasa kedua yang menekankan pada aspek formal bahasa semakin berkembang akhir-akhir ini. Menurut Brumfit dan Johnson dalam Johnson 
$(\text { ed. })^{5}$, masalah yang dihadapi oleh para pelajar ialah mereka memiliki kompetensi secara struktural, padahal pengajaran bahasa struktural tidak memungkinkan para pelajar untuk melihat penerapan bahasa secara praktis di dalam kenyataan yang sebenarnya.

\section{B. Struktur Wacana}

Suatu wacana dituntut memiliki keutuhan struktur. Keutuhan itu dibangun oleh komponen-komponen yang terjalin di dalam suatu organisasi kewacanaan. ${ }^{6}$ Organisasi inilah yang disebut sebagai struktur wacana. Sebagai sebuah organisasi, struktur wacana dapat diurai atau dideskripsikan bagian-bagiannya.

\section{Aspek-aspek Keutuhan Wacana}

Wacana yang utuh ialah wacana yang lengkap, yaitu mengandung aspek-aspek yang terpadu dan menyatu. Aspek- aspek itu menurut Mulyana ialah kohesi, koherensi, topik wacana, aspek leksikal, aspek gramatikal, aspek fonologis, dan aspek semantik ${ }^{7}$. Lanjut Mulyana, keutuhan wacana juga didukung oleh setting atau konteks terjadinya wacananya tersebut. Jadi, secara komprehensif dapat dikatakan bahwa keutuhan wacana dapat terjadi dari adanya saling keterkaitan antara dua aspek utama wacana, yaitu teks dan konteks.

Beberapa aspek pengutuh wacana yang disebutkan di atas dapat dikelompokkan ke dalam dua unsur, yaitu unsur kohesi dan unsur koherensi. Unsur kohesi meliputi aspekaspek leksikal, gramatikal, fonologis, sedangkan aspek koherensi mencakup aspek semantik dan aspek topikalisasi. Oleh karena itu kedua aspek tersebut dibahas secara lebih proporsional.

\section{Metodologi Penelitian}

Penelitian ini menggunakan pendekatan kualitatif, khususnya pendekatan analisis wacana. Jadi, alat utama penelitian ini ialah peneliti sendiri. Data berbentuk data dokumenter, yaitu pemakaian bahasa Indonesia dalam skripsi mahasiswa. Dengan demikian hlm. 121

${ }^{5}$ Keith Johnson (ed.), Communicative Syilabus Design and Methodology (Oxford: Pergamon Press, 1982),

${ }^{6}$ Mulyana. Kajian Wacana: Teori, Metode dan Aplikasi PrinsipPrinsip Analisis Wacana (Yogyakarta: Tiara Wacana, 2005), hlm 25.

${ }^{7}$ Mulyana,op. cit., h.25 
data penelitian ini berkaitan dengan suatu gejala kebahasaan yang sifatnya alamiah. Artinya data yang dikumpulkan berasal dari lingkungan nyata dan situasi apa adanya. Sedangkan, metode yang digunakan dalam penelitian ini adalah metode deskriptif. Hal ini disebabkan oleh karena data yang terkumpul dianalisis dan dipaparkan secara deskriptif.

Data penelitian ini berbentuk data dokumenter, yaitu pemakaian bahasa Indonesia dalam skripsi mahasiswa STAIN Manado. Data dokumenter tersebut berupa kata sebagai penanda wacana dalam karya tulis. Sumber data dari penelitian ini adalah pemakaian bahasa Indonesia dalam karya tulis (skripsi) mahasiswa STAIN Manado.

Teknik pengumpulan data yang dilakukan dalam penelitian ini adalah teknik observasi sebagai teknik utama. Observasi dilakukan dengan cara baca-catat, yaitu peneliti membaca dan mencatat data bahasa dengan teknik analisis wacana. Melalui teknik observasi ini, dengan cara pengamatan partisipan oleh peneliti sendiri, maka akan diperoleh data yang waj ar dan alami.

Data-data yang terkumpul dianalisis dengan menggunakan teknik analisis wacana. Jenis-jenis penanda keterpaduan wacana yang diperoleh dimuatkan contohnya. Namun, contoh-contoh yang dimuat akan dibatasi jumlahnya untuk menghindari pemuatan contoh dengan tipe atau jenis penanda wacana yang sama. Pembatasan contoh dilakukan dengan cara pemuatan contoh yang tepat penggunaannya dan yang salah penggunaannya. Hanya contoh yang langkah yang akan diusahakan untuk memberi semua contoh keterpaduan yang terdapat dalam skripsi itu.

Setiap contoh yang dimuat diberi komentar, baik dari segi ketepatannya maupun dari segi kesalahan pemakaiannya dalam bentuk memberikan usulan perbaikannya. Data yang diperoleh dideskripsikan dan digolong-golongkan berdasarkan tipe-tipe penanda wacana yang ada. Berdasarkan hal tersebut, maka penelitian ini termasuk penelitian deskriptif analitis.

\section{B. Penggunaan Penanda Wacana}

Berdasarkan data penelitian, jenis-jenis keterpaduan yang digunakan oleh para mahasiswa dalam skripsi mereka yaitu pengulangan leksikal, transisi, substitusi, pernyataan kembali, syarat, pemberian contoh, kata penghubung, referensi, praanggapan, pelesapan (zero), sebab-akibat, alasan, penambahan, proverb, deiksis, antonimi, alternatif, kata tumpuan, simpulan/ hasil, kontras, dan pengurutan.

Contoh-contoh penggunaan penanda keterpaduan yang digunakan oleh mahasiswa 
dalam laporan penelitian skpripsinya itu disajikan di bawah ini untuk melihat ketepatan penggunannya di samping sebagai bukti penggunannya. Sebagai komentar, alat keterpaduan yang paling banyak digunakan ialah penggunaan leksikal dan penanda transisi.

\section{Pengulangan Leksikal}

Pengulangan leksikal dalam wacana karya tulis mahasiswa ada yang tepat dan ada pula yang tidak tepat. Contoh pengulangan leksikal yang tepat

Contoh (1)

"Seiring dengan perkembangan zaman, di mana dunia senantiasa terus mengalami perubahan. Perubahan ini sejalan dengan perkembangan pemikiran manusia yang memang diamanatkan sebagai khalifah fil ‘ardh (pemimpin bumi) yang telah difirmankan Allah SWT dalam QS. AlBaciarah."

Kata yang diulang pada contoh (1) di atas adalah perubahan. Pada kalimat pertama kata perubahan berposisi sebagai objek, sedangkan pada kalimat berikutnya kata perubahan berfungsi sebagai subjek. Pemakaian bentuk seperti itu dinilai tepat dari sudut kaidah bahasa sehingga tidak terjadi kesenjangan. Pemakaian kata ini juga digunakan sebagai penanda definitif untuk menunjuk kata perubahan yang sudah disebutkan sebelumya sehingga tidak menimbulkan keraguan.

Dalam hal lain ada pula bentuk pengulangan leksikal yang kurang tepat sebgaimana contoh berikut.

Contoh (2)

"Pada dasarnya UU SPN tahun 2003 merupakan bagian dari suatu pembaharuan pendidikan oleh pemerintah untuk dapat meningkatkan kualitas dan efisiensi pendidikan. Usaha pembaharuan tersebut antara lain pemberian otonomi kepada sekolah."

Dalam kalimat kedua pada contoh (2) terdapat kata usaha mendahului kata pembaharuan yang diulang. Hal ini menyebabkan jalan pikiran penulis sukar diikuti. Mestinya dijelaskan oleh peneliti bahwa pembaharuan itu merupakan suatu usaha, atau tanpa kata usaha, kalimat itu tetap berpadu sekalipun hanya merupakan pengulangan murni.

\section{Transisi}


Penanda transisi juga lazim digunakan mahasiswa dalam wacana karya tulis ilmiah. Berikut adalah contoh penggunaannya yang tepat.

Contoh (3)

"Setiap orang mempunyai hak dan kewajiban untuk berperan serta dalam pengelolaan pendidikan. Dalam kaitan ini lembaga sekolah ...".

Pemakaian frase dalam kaitan ini pada contoh (3) sebagai penanda transisi dinilai sangat tepat. Tanpa frase seperti itu, hubungan kedua kaimat itu dinilai longgar. Artinya, kalau kalimat berikutnya langsung dimulai dengan kata lembaga, maka pernyataan yang dibuat seolah-olah berdiri sendiri terlepas dari kalimat sebelumnya.

Dalam hal lain, juga ditemukan penggunaan penanda transisi yang kurag tepat sebagaimana contoh berikut.

Contoh (4)

"Secara psikologis belajar merupakan suatu proses perubahan tingkah laku sebagai hasil dari interaksi dengan lingkungannya dalam memenuhi kebutuhan

hidupnya. Sejalan dengan itu, Slameto juga mengungkapkan beberapa ciri-ciri yang dapat mengindikasikan bahwa seseorang yang belajar telah memiliki beberapa perubahan".

Pemakaian frase sejalan dengan itu pada contoh (4) dinilai kurang tepat untuk menghubungkan kalimat yang ada. Karena frase sejalan dengan itu merupakan pernyataan yang sifatnya menudukung atau menguatkan pernyataaan sebelumnya. Dalam kalimat

pertama dijelaskan tentang konsep belajar. Seharusnya, pemakaian frase sejalan dengan itu pada kalimat kedua juga berkaitan dengan konsep belajar yang dikemukakan pada kalimat sebelumnya.

\section{Substitusi}

Selain pengulangan leksikal dan penanda transisi, bentuk substitusi juga sering digunakan oleh mahasiswa dalam wacana karya tulis ilmiah. Perhatikan contoh berikut.

\section{Contoh (5)}

"Seorang guru harus mengetahui setiap potensi yang dimiliki oleh setiap siswanya.

Hal ini penting untuk dij adikan bekal dalam pemilihan metode, pendekatan atau 
strategi pembelaj aran yang akan diharapkan, sehingga dapat memusatkan perhatian pada perbedaan yang dimiliki siswa".

Frase hal ini dalam contoh (5) merupakan bentuk subsitusi atau penggantian pernyataan pada kalimat pertama yaitu "Seorang guru harus mengetahui setiap potensi yang dimiliki oleh setiap siswanya". Kalimat tersebut memiliki hubungan kepaduan sehingga dapat nilai tepat. Cara substitusi seperti ini sebagai salah satu cara peyusunan kalimat yang efektif dan efesien dalam menyampaikan pesan kepada pembaca. Tulisan yang baik akan ditunjukkan oleh ketepatan penggunaan alat-alat kebahasaan.

Hal ini berbeda dengan contoh berikut.

\section{Contoh (6)}

"Dalam rencana tata ruang kota Manado peruntukan lahan pesisir dibagi 84\%, sisanya dikelola oleh Pemerintah Kota Manado. Indikator-indikator ini merupakan gambaran transformasi kota Manado menjadi kota Jasa dan perdagangan dengan membuka diri pada arcs masuk modal domestik".

Kata indikator pada contoh (6) tiba-tiba muncul tanpa diperkenalkan lebih dahulu. Asumsi penulis ialah peruntukan lahan pesisir dibagi 84\%, sisanya dikelola oleh Pemerintah Kota Manado merupakan indikator transformasi kota Manado menjadi kota $\mathrm{j}$ asa dan perdagangan. Pemakaian kata indikator sebagai penghubung kedua kalimat itu kurang tepat.

Sebaiknya penulis harus secara eksplisit dulu menjelaskan bahwa semua yang akan disebut itu merupakan indikator transformasi kota Manado menjadi kota Jasa dan perdagangan. Karena kata indikator yang muncul pada kalimat kedua merupakan pengganti dari peruntukan-peruntukan lahan yang disebut pada kalimat pertama, maka penanda keterpaduan kalimat di sini dikategorikan sebagai substitusi.

\section{Pernyataan Kembali}

Bentuk penanda wacana lain yang digunakan ialah penyataan kembali. Perhatikan contoh berikut.

\section{Contoh (7)}

"Perkawinan merupakan salah satu sunnatullah yang telah ditetapkan Allah swt sebagai suatau kodrat yang

terj adi pada kehidupan manusia untuk 
berkesinambungan keturunannya. Dengan kata lain, melalui perkawinan akan tercipta suasana yang dapat memudahkan jalan dalam pencapaian kehidupan yang mawaddah dan warahmah menuju kebahagiaan lahiriah dan batiniah secara hakiki".

Pemakaian pernyataan kembali dalam bentuk dengan kata lain pada contoh (7) dapat dinilai tepat. Namun demikian, konteks kalimat pertama sebenarnya memuat pernyataan tentang hakikat perkawinan sehingga pada kalimat kedua yang dimarkahi oleh kohesi pernyataan kembali dengan kata lain seharusnya juga memuat pernyataan tentang hakikat perkawinan yang telah disebut pada kalimat sebelumnya. Oleh karena itu, logika penulis agak sulit diikuti.

Penggunaan frase dengan kata lain sebagai kohesi pernyataan kembali digunakan secara tepat sebagaimana terdapat dalam contoh berikut.

Contoh (8)

"Sewa-menyewa yaitu suatu persetujuan yang mana pihak yang satu mengikuti dirinya untuk memberikan kepada pihak yang lainnya kenikmatan dari suatu barang, selama waktu tertentu dengan pembayaran sesuai harga yang pihak tersebut menyanggupi pembayarannya. Dengan kata lain, sewa-menyewa yakni menyerahkan sesuatu hak miliki kepada orang lain untuk diambil manfaatnya dalam jangka waktu yang sudah ditentukan dan termuat dalam surat perjanjian (akad) antara kedua belah pihak".

\section{Syarat}

Bentuk syarat sebagai penanda wacana yang digunakan dalam wacana karya tulis ilmiah mahasiswa sebagaimana dapat dilihat dalam contoh berikut.

Contoh (9)

"Tata krama dan sopan santun adalah topik yang tak habis-habisnya dibahas dalam kehidupan sehari-hari. Bagaimana menghormati orang tua, guru dan teman sebaya adalah sikap yang harus dibina sejak usia dini. Apabila orang tua dan guru selalu memberikan nasehat tentang perbuatan baik untuk dikerjakan dan perbuatan jelek untuk ditinggalkan, maka setiap anak mengetahui perbuatan baik dan perbuatan tercel".

Alat pemadu kalimat pada contoh (9) ialah syarat, yaitu apabila. Syarat ini kalau 
tidak dipenuhi akan tidak terjadi seperti yang diharapkan. Hubungan syarat tersebut digunakan secara tepat oleh penulisnya.

Berbeda dengan contoh berikut, penggunaan syarat sebagai penanda wacana dinilai kurang tepat sebagaimana tampak dalam contoh kutipan.

Contoh (10)

"Keberhasilan dalam suatau interaksi edukatif, atau

hasil sebuah kegiatan belajar mengajar, sangat ditentukan oleh keharmonisan hubungan kedua subjek di atas, yaitu antara guru dan siswa. Bila tidak tercipta hubungan yang harmonis dalam suatu kegiatan belajar mengajar, maka akan sulit untuk sampai pada tujuan pembelajaran yang telah direncanakan oleh guru dalam Satuan Acara Pembelajaran (SAP)".

Dilihat dari segi kata bila sebagai pembuka kalimat pada contoh (10), maka hubungan kedua kalimat itu dipertalikan oleh kata yang berarti syarat. Akan tetapi, kalau dilihat dari segi frase pembuka kalimat kedua, maka hubungan itu diantarkan oleh frase transisi. Yang kurang di sini ialah dilesapkannya subjek pada klausa terakhir sehingga klausa itu tidak lagi bersubjek dan hal ini mengurangi, bahkan menimbulkan kesalahan struktur. Hubungan syarat sekaligus dengan penanda transisi, dibuat lagi oleh penulis yang lain. Kali ini subjek pada klausa kedua tidak dilesapkan seperti terlihat dalam contoh.

\section{Pemberian Contoh}

Pemberian contoh sebagai alat penanda wacana yang digunakan mahasiswa sebagaimana tampak dalam contoh berikut.

\section{Contoh (11)}

"Faktor lingkungan pendidikan terdiri dari lingkungan sekolah, masyarakat, dan keluarga. Salah satu faktor lingkungan yang merupakan bagaian sangat vital dalam pembetukan nilai anak didik adalah faktor lingkungan keluarga".

Hubungan kedua kalimat dalam contoh (11) di atas berjalan dengan pemberian contoh konkret. Contoh yang dimaksud salah satu faktor lingkungan. Dalam frase transisi tersebut terkandung pemberian contoh salah satu yang menunjukkan bahwa hal yang disebut pada kalimat kedua secara tegas mengacu pada salah satu contoh yang telah telah disebut sebelumnya. 


\section{Kata Penghubung}

Penggunaan kata penghubung juga sangat lazim digunakan dalam wacana tulis karya ilmiah mahasiswa. Perhatikan contoh berikut.

Contoh (12)

"sehingga seseorang yang mempunyai tingkat pendidikan cukup tinggi akan lebih sensitif dan cepat tanggap untuk memahami berbagai peristiwa."

Pemakaian kata penghubung sehingga pada contoh (12) di atas tidak tepat karena kata sehingga hanya menghubungkan dua buah klausa bukan kalimat. Kata sehingga tidak tepat digunakan untuk memulai suatu kalimat melainkan hanya memulai suatu klausa.

Contoh (13)

"Sedangkan SMP Negeri 1 Bintauna, sebagaimana pengamatan awal dari penulis, terdapat indikasi kuat tentang fenomena kenakalan siswa pada saat proses pembelaj aran berlang sung".

Kata sedangkan untuk memulai suatu kalimat haruslah berpasangan dengan frase apa lagi dalam bentuk "Sedangkan ... apalagi ..." Kata sedangkan yang digunakan selain dari pasangan tersebut di atas hanya dapat menghubungkan dua buah klausa, bukan kalimat. Karena penulis menggunakan kata tersebut di awal kalimat tanpa berpasangan dengan frase apalagi, maka pemakaian kata sedangkan dalam konteks itu tidak tepat.

\section{Referensi}

Bentuk rerefensi juga digunakan oleh mahasiswa dalam penanda wacana karya tulis ilmiahnya. Perhatikan contoh berikut.

Contoh (14)

"Namun hal semacam ini justru tidak diperhatikan

oleh orang tua dengan alasan dan sebab bahwa mereka lebih mengutamakan pekerj aan-pekerj aan

yang bersifat duniawi dari pada memperhatikan pendidikan anak".

Kata mereka pada contoh (14) di atas mengacu kepada orang tua pada kalimat sebelumnya sehingga kedua kalimat itu terpadu secara utuh. Namun demikian, kalimatnya yang rancuh mengakibatkan jalan pikiran penulis sukar ditebak. Kalimat itu seharusnya berbunyi "Hal semacam ini justru tidak diperhatikan oleh orang tua sebab mereka lebih 
mengutamakan pekerj aan-pekerj aan yang bersifat duniawi dari pada memperhatikan pendidikan anak".

Pemakaian substitusi yang tepat dapat dilihat pada contoh berikut.

\section{Contoh (15)}

"Memasuki abad ke -21 banyak pemikir ekonomi - -khususnya kaum muslim-- yang kembali menekankan pemakaian uang dinar dan dirham di perekonomian global. Bagi mereka, sistem tukar dinar dan dirham lebih adil untuk masyarakat dunia saat ini tanpa memandang asal-usul kebangsaan dan sebagainya".

Kata mereka pada contoh (15) mengacu pada banyak pimikir ekonomi --khususnya kaum muslim--,yang telah disebutkan pada kalimat pertama. Kalimat ini dapat dinilai memiliki kepaduan yang sangat kuat.

\section{Praanggapan}

Penanda wacana lainnya yang juga digunakan oleh mahasiswa ialah jenis praanggapan sebagaimana tampak dalam contoh berikut.

Contoh (16)

"Islam sebagai agama yang sempurna mengatur seluruh aktivitas manusia yang termasuk di dalamnya pengaturan tentang tata cara penyelenggaraan perkawinan. Dalam kaidah ini tentunya memiliki berbagai fadillah dan hikmah yang akan didapatkan oleh suami isteri dalam melayari bahterah rumah tangga sleanjutnya".

Tata cara penyelenggaraan perkawinan dipraanggapkan sebagai kaidah. Kaidah dalam logika penulis itu tentulah merujuk pada kaidah sebagaimana diatur dalam hukum Islam. Karena itu pemakaian kata kaidah yang dipraanggapkan dengan frase tata cara penyelenggaraan perkawinan ini dapat dinilai tepat.

\section{Pelesapan}

Bentuk penanda wacana lainnya yang digunakan oleh mahasiswa dalam wacana karya tulis ilmiahnya ialah jenis pelesapan sebagaimana contoh berikut.

Contoh (17)

"Indikator merupakan penanda pencapaian kompetensi dasar yang ditandai oleh perubahan perilaku yang dapat diukur yang mancakup sikap, pengetahuan, dan 
keterampilan. Dikembangkan sesuai karakteristik peserta didik, mata pelajaran, satuan pendidikan, potensi daerah dan dirumuskan dalam kata kerja operasional yang terukur dapat diobservasi".

Kedua kalimat pada contoh (17) di atas ditautkan dengan adanya bentuk pelesapan subjek pada kalimat kedua, yaitu kata indikator. Pelesapan yang digunakan tesebut tidak tepat karena pelesapan subjek pada kalimat kedua ini mengurangi keterpaduan kalimat. Pelesapan yang benar adalah terdapat pada klausa kedua pada kalimat kedua. Jadi, kalimat kedua menjadi "Indikator dikembangkan sesuai karakteristik peserta didik, mata pelajaran, satuan pendidikan, potensi daerah dan (indikator: lesap) dirumuskan dalam kata kerja operasional yang terukur dapat diobservasi".

\section{Sebab Akibat}

Bentuk sebab akibat sebagai penanda wacana juga sering digunakan. Perhatikan contoh berikut.

Contoh (18)

"Karena apabila pendidikan agama diabaikan atau diremehkan oleh sekolah, didikan agama yang diterimanya di rumah, tidak akan berkembang, bahkan mungkin terhalang, ....Karena itu, sekolah adalah lingkungan efektif untuk menanamkan pendidikan agama bagi anak-anak....".

Penggunaan bentuk penghubung karena itu yang mengandung arti sebab akibat untuk menghubungkan kedua kalimat pada contoh (18) di atas dinilai tepat karena pernyataan penyebaban pada kalimat kedua merupakan bentuk penyimpulan dari pernyataan pada kalimat pertama. Namun demikian, kata karena yang digunakan sebagai pembuka kalimat pertama tanpa diikuti kata maka pada kalimat petrtama menjadikan kalimat itu kurang padu. Bentuk karena sebagai kata yang berdiri sendiri hanya digunakan untuk menghubungkan klausa dua buah klausa yang memiliki bertingkat.

\section{Alasan}

Bentuk alasan sebagai penanda wacana karya tulis ilmiah juga digunakan oleh mahasiswa sebagaimana dapat dilihat dalam contoh berikut. 
Contoh (19)

"Jadi menurut hemat penulis, akhlak merupakan inti dari pendidikan awal yang harus diperhatikan oleh pendidik dan peserta didik. Karena dengan akhlak manusia akan memiliki kepribadian yang mulia".

Pemakaian kata karena di awal kalimat tanpa diimbangi kata maka pada contoh (19) tidaklah tepat. Pemakaian kata karena seperti itu hanya terjadi pada awal klausa sebagai penanda alasan. Jadi, penggunaan karena pada kalimat kedua dinilai tidak tepat.

\section{Penambahan}

Bentuk yang lain ialah jenis penambahan. Perhatikan contoh berikut.

Contoh (20)

"Dalam hal ini setiap pendidik wajib mencerminkan keteladanan yang baik untuk anak didiknya. Namun hal semacam ini tidak diperhatikan oleh orang tua dengan alasan dan sebab bahwa mereka lebih mengutamakan pekerjaan-pekerjaan yang bersifat duniawi dari pada memperhatikan pembinaan anak. Di lain pihak, ada juga orang tua yang memiliki perhatian terhadap anaknya tetapi mereka sendiri tidak faham apa yang seharusnya dilakukan terhadap anaknya".

Pemakaian penambahan di lain pihak pada contoh (20)

ialah untuk mempertentangkan sesuatu. Karena hal ini tidak demikian, maka penambahan yang tepat ialah di camping itu dengan maksud menambah pernyataan untuk memperkuat argumentasi atau penjelasan.

\section{Proverba}

Selain penambahan, jenis proverba juga tampak dalam penanda wacana karya tulis ilmiah mahasiswa. Perhatikan contoh berikut.

Contoh (21)

"Memang setiap manusia punya kebutuhan masingmasing. Tetapi kalau_demikian berlebihan inilah yang sangat tidak etis dalam ajaran Islam". 
Pemakaian kata demikian memberi kesan bahwa ada suatu yang ditunjuk dalam bentuk proverba. Dalam tulisan tersebut penempatan kata demikian tidak tepat. Hal ini berbeda dengan contoh berikut.

Contoh (22)

"Di tiap-tiap sekolah sedapat mungkin harus ada satu kantor/biro bimbingan dan penyuluhan yang akan menampung dan memberikan tuntunan khusus bagi anak yang membutuhkannya. Hal seperti ini untuk mencegah meluasnya dan menularnya akhlak yang kurang baik dari seorang anak didik kepada kawannya yang lain". (JT 1, 22)

Kata seperti ini pada contoh (22) mengacu kepada kantor/biro bimbingan dan penyuluhan yang akan menampung dan memberikan tuntunan khusus bagi anak. Pemakaian seperti ini sebagai bentuk proverba dapat dinilai tepat.

\section{Deiksis}

Berikutnya adalah deiksis. Bentuk deiksis juga digunakan sebagai penanda wacana karya tulis ilmiah. Perhatikan contoh berikut.

Contoh (23)

"... diperlukan ruangan khusus untuk pembinaan akhlak anak didik seperti satu kantor/biro bimbingan dan penyuluhan sebagaima telah dikemukakan. Di sini anak didik dapat diberikan bimbingan dan penyuluhan".

Kata di sini pada contoh (23) mengacu kepada tempat yang disebut kantor/biro bimbingan dan penyuluhan. Penggunaan kata di sini dinilai tepat sehingga kedua kalimat itu berpadu dengan baik.

Sejenis dengan deiksis di sini ialah frase di atas yang banyak digunakan dalam skripsi mahasiswa. Frase di atas umumnya digunakan secara keliru karena mengacu kepada bagian lain dari tulisan penulis yang terdapat di depan, bukan tempat lain yang sedang dibahas.

\section{Antonimi}

Temuan lain ialah penggunaan antonimi. Penggunaannya dalam wacana karya tulis ilmiah mahasiswa sebagaimana tampak dalam contoh berikut.

Contoh (24)

"Bagi seorang anak yang memiliki kemampuan yang memadai atau di atas rata-rata tentunya akan dengan mudah memahami setiap materi yang dikemukakan oleh seorang 
guru. Lain halnya jika diperhadapkan dengan siswa yang memiliki tingkat kemampuan $d i$ bawah standar".

Frase memadai atau di atas rata-rata berlawanan dengan frase di bawah standar. Pemakaian kedua frase itu sebagaimana contoh (24) menyebabkan kedua kalimat yang dipadukan menjadi benar-benar berpadu. Walaupun bentuk antonim yang lebih tepat dari frase di atas rata-rata adalah di bawah rata, jalan pikiran penulis sudah dapat ditebak yang menunjukkan bahwa kalimat itu berhubungan. Untuk memberikan penegasan terhadap sesuatu cara efektif yang dapat dilakukan ialah dengan menggunakan antonimi. Bentuk antonomi ini juga merupakan bagian dari unsur pemadu wacana atau alat keutuhan wacana.

\section{Alternatif}

Penanda wacana yang juga ditemukan ialah bentuk alternatif. Penggunaannya daalam wacana sebagaimana tampak dalam contoh berikut.

Contoh (25)

"... Hal ini bisa ditempuh dengan

mengadakan studi banding ke sekolah-sekolah lain. Atau dengan membaca bukubuku yang memiliki topik yang sama dengan togas dan tanggung jawabnya".

Kata atau pada contoh (25) memberi kesan bahwa terdapat alternatif dari pernyataan yang mendahului. Alternatif itu terdapat dalam kalimat yang mengikuti kalimat terdahulu. Kedua kalimat itu lebih tepat dihubungkan dengan unsur penambahan yaitu frase selain itu. Kata atau yang digunakan penulis sebagai pembuka kalimat juga dinilai tidak tepat karena atau hanya menghubungkan klausa bukan kalimat.

\section{Kata Tumpuan}

Jenis penanda wacana berikutnya ialah kata tumpuan. Perhatikan contoh berikut. Contoh (26)

"Guru sebagai pendidik mestilah menjadi teladan akhlak mulia bagi anak ddik. Bahwa pendidik mestilah mencermkinkan sikap dan perilakunya yang dapat ditiru oleh anak didik".

Pemakaian kata bahwa tidak tepat. Kalau hal itu dipandang sebagai kata tumpuan, maka pernyataan yang mengikutinya berbentuk frase atau kalimat yang belum selesai karena 
ia merupakan anak kalimat dari sebuah kalimat kompleks.

\section{Simpulan}

Selain itu, juga ditemukan penggunaan penanda wacana jenis simpulan. Perhatikan contoh berikut.

Contoh (27)

"Hidup bersama manusia akan berangsung dalam berbagai bentuk komunikasi dan situasi. Dalam kehidupan semacam inilah terjadi interaksi.

Dengan demikian kegiatan hidup manusia akan selalu dibarengi dengan kegiatan interaksi atau komunikasi, baik interaksi dengan alam lingkungan interaksi dengan sesamanya, maupun interaksi dengan Tuhannya, baik itu disenjaga maupun tidak disengaja".

Seperti telah disebutkan di atas, frase dengan demikian menyimpulkan tentang pernyataan sebelumnya sehingga ia searti dengan kata jadi.

\section{Kontras}

Untuk menandai wacana, penulis juga menggunakan bentuk kontras sebagaimana contoh berikut.

Contoh (28)

"Di sate sisi secara positif ilmu pengetahuan dan teknologi telah mengantarkan kehidupan manusia ke dalam kehidupan yang lebih modern. Ia telah mampu merekayasa kebutuhan-kebutuhan manusia dan menawarkan berbagai kemudahan bagi manusia untuk memperoleh kesenangan. Namun sebaliknya, tidak dipungkiri bahwa secara negatif dapat dirasakan kehidupan yang semakin rendah terpuruk dalam kegelapan.

Pemakaian frase namun sebaliknya pada contoh (28) dinilai berlebihan. Cukup digunakan salah satunya. Dilihat dari segi lain, hubungan kedua kalimat itu akan lebih kuat dan nilai komunikasinya akan lebih efektif kalau hanya menggunakan penanda kontras sebaliknya. Selain itu, hubungan kedua kalimat itu menjadi longgar akibat penggunaan bentuk kohesi pelesapan pada subjek pada kalimat kedua. Dalam kalimat kedua itu seharusnya subjek ilmu pengetahuan dan teknologi tetap harus disebut sehingga kalimatnya menjadi padu. 


\section{Pengurutan}

Jenis penanda wacana yang terakhir ialah pengurutan. Hal ini tampak pada contoh berikut.

Contoh (29)

"Contohnya, ketika bertepuk tangan secara tiba-tiba di samping seorang anak akan menimbulkan kekagetan/keterkejutan, namun bila tepuk tangan itu dilakukan berulang-ulang maka rasa terkejut itu akan menghilang. Selanjutnya melalui pengkondisian anak dalam sate kelas yang merupakan bentuk belajar netral (biasa) yang sering digunakan dalam pembelaj aran".

Pemakaian kata selanjutnya pada contoh (29) dengan maksud mengurutkan malahan merusak kontinuitas kalimat. Mestinya cukup dengan penanda transisi "melalui pengkondisian anak ....".

Ketidaktepatan penggunaan kohesi pengurutan juga dilakukan oleh penulis lain seperti dalam contoh berikut. Contoh (30)

"Pemegang akta memiliki hak untuk menukarkan aktanya tersebut dengan barangbarang yang ingin dimilikinya. Selanjutnya pedagang yang menerima akta ini dapat pula melakukan pertukaran yang sama atau dapat is tukarkan dengan koin emas pada lembaga yang memiliki otoritas penukaran".

Pemakaian kata selanjutnya untuk memulai kalimat kedua dinilai tidak tepat. Tanpa kata itu pun kedua kalimat masih rapat hubungannya atau tetap kohesif.

\section{Kecenderungan Pemakaian Jenis Keterpaduan}

Di antara jenis-jenis keterpaduan yang digunakan oleh para mahasiswa dalam skripsi mereka, terdapat dua jenis yang cenderung lebih dominan, yaitu pengulangan leksikal. dan transisi. Kedua jenis itu tampaknya berimbang.

Baik pemakaian pengulangan leksikal, maupun pemakaian transisi dari kedua kelompok jurusan (Jurusan Tarbiyah dan Jurusan Syari'ah), masing-masing menunjukkan proporsi kesalahan yang sama. Artinya, tidak dapat disebutkan bahwa kelompok Tarbiyah lebih dominan membuat kesalahan. Demikian pula sebaliknya. Hal ini menunjukkan bahwa mahasiswa dari kedua kelompok jurusan itu belum 
sepenuhnya menguasai cara-cara pemakaian alat pemadu wacana itu dalam tulisannya.

Untuk jenis keterpaduan lainnya, dapat dikatakan tidak ada yang menonjol. Jumlah yang ditemukan antara satu sampai empat buah. Pemakaian yang hanya sebuah belum juga dapat dipastikan bahwa pemunculan itu merupakan suatu kebetulan karena kebutuhan pemakaiannya memang demikian. Di samping itu, pengamatan yang dilakukan hanya terbatas. Jumlah buku skripsi yang diamati hanya 20 buah di antara ratusan buku skripsi yang dibuat oleh mahasiswa. Di samping itu jumlah halaman yang diamati juga terbatas karena yang diambil hanyalah kelipatan empat. Hal itu berarti bahwa hanya seperempat bagian dari setiap buku skripsi. Ini setidaksetidaknya merupakan bagian dari keterbatasan penelitian ini. Namun demikian, hasil penelitian ini paling tidak dapat menjadi dasar atau pertimbangan dalam penelitian selanjutnya.

\section{Penutup}

Berdasarkan data temuan penelitian ini, maka dapatlah dikemukakan bahwa jenisjenis keterpaduan yang digunakan oleh para mahasiswa dalam skripsi mereka dikelompokkan menurut jenisnya, yaitu (1) pengulangan leksikal, (2) transisi, (3) substitusi, (4) pernyataan kembali, (5) syarat, (6) pemberian contoh, (7) kata penghubung, (8) referensi, (9) praanggapan, (10) pelesapan (zero), (11) sebab-akibat, (12) alasan, (13) penambahan, (14) proverba, (15) deiksis, (16) antonimi, (17) alternatif, (18) kata tumpuan, (19) simpulan/hasil, (20) kontras, dan (21) pengurutan. Dari deretan penanda keterpaduan wacana tersebut, bentuk pengulangan lekiskal dan transisi sangat dominan penggunaannya. Bentuk yang juga relatif sama dominannya ialah bentuk kata penghubung. Pada umumnnya 
mahasiswa pada dua kelompok Jurusan (Tarbiyah dan Syariah)

menunjukkan tingkat kesalahan yang relatif sama dalam penggunaan kohesi leksikal. Artinya, mahasiswa mempunyai kebiasaan yang sama dalam penggunaan alat-alat kohesi wacana ini.

Untuk pananda transisi juga demikian, baik kelompok Jurusan Syariah maupun kelompok Jurusan Tarbiyah masingmasing menunjukkan proporsi kesahalan yang relatif sama. Kata penghubung yang bahkan lazim digunakan oleh para mahasiswa juga tampak kesalahan yang menonjol. Hal ini menunjukkan ketidakcermatan mahasiswa menuangkan gagasannya dalam bahasa verbal. Hal ini juga menunjukkan bahwa jalan pikiran mahasiswa kadang-kadang tidak tersusun rapi. Hal ini tampak juga pada referensi yang bahkan sangat sering digunakan oleh mahasiswa.

Pemakaian penanda pengurutan tampak adanya kejanggalan. Penanda yang digunakan ialah pengurutan, tetapi kesan yang diperoleh bukanlah pengurutan tetapi serangkaian pernyataan yang keberadaannya tidak dalam urutan waktu (time). Berdasarkan temuan yang diperoleh maka dapat disimpulkan bahwa kemampuan mahasiswa untuk memadukan kalimat-kalimat yang berdekatan (adjacent sentence) masih sangat kurang. Banyak hubungan kalimat yang dinilai renggang atau penanda keterpaduannya salah pakai.

Berdasarkan temuan penelitian ini, saran yang dapat dikemukakan ialah (1) kebiasaan menulis hendaknya ditumbuhkan sejak awal pendidikan formal dan dipupuk pada jenjang pendidikan formal tertinggi, (2) salah satu aspek yang perlu diperkuat dalam pelajaran menulis ialah aspek keterpaduan wacana. Hal itu sangat perlu diperhatikan karena kejemihan jalan pikiran penulis tercermin dalam urutan kalimatnya. Urutan kalimat yang tidak logis hanya merupakan tumpukan kalimat dan bukannya rangkaian kalimat, (3) karena kesalahan pemakaian bahasa ternyata masih sering didapatkan dalam skripsi, maka para mahasiswa yang akan atau sedang menyusun skripsi hendaknya lebih memperhatikan aspek kaidah bahasa yang digunakan terutama cara merangkai kalimat untuk menunjukkan kejernihan logika berpikirnya, (4) dosen pembimbing penulisan skripsi hendaknya mencermati kaidah bahasa yang digunakan oleh para mahasiswa, (5) dalam penelitan ini ditemukan bahwa pemarkah keterpaduan yang sangat sederhana seperti referensi dan kata penghubung pun justru kurang sempurna pemakaiannya. Berdasarkan hal tersebut maka 
disarankan agar dibentuk komisi pemeriksa akhir skripsi yang secara khusus memeriksa aspek penggunaan bahasa dalam skripsi, dan (6) walaupun telah diupayakan secara maksimal, penelitian ini barangkali belumlah lengkap dan masih banyak hal yang dapat dikaji lebih lanjut. Oleh karena itu, penelitian sejenis perlu dilakukan dengan mengambil permasalahan yang lebih luas. 


\section{Daftar pustaka}

Johnson, Keith. 1982. Communicative Syilabus Design and Methodology. Oxford: Pergamon Press.

Mulyana. 2005. Kajian Wacana: Teori, Metode dan Aplikasi Prinsip-prinsip analisis wacana. Yogyakarta: Tiara Wacana

Sadtono, E, “ Bahasa Indonesia Tertulis Golongan Terdidik (Sarjana) di Indonesia.” Dalam majalah Pengajaran Bahasa dan Sastra. Thn I No. 5. Tahun 1976. Jakarta: Pusat Pembinaan dan Pengajaran Bahasa

Syafi'i, Imam. 1984. “ Analisis Kesalahan Berbahasa dalam Menulis Mahasiswa Tiga IKIP di Jawa.” Malang :IKIP. Disertai, tidak dipublikasikan.

Sugihastuti. 2003. Bahasa Indonesia dari awam, Mahasiswa, sampai wartawan. Yogyakarta : Gama Media.

Tallei. 1992. “Pemakaian Bahasa Indonesia dalam Buku Laporan Penelitian Dosen LPTK di Sulawesi Utara”. Laporan Penelitian. Manado : IKIP Manado. 